\title{
'Remembering God' through Religious Habits: The Daily Religious Practices of Evacuee Karelian Orthodox Women ${ }^{1}$
}

\author{
HELENA KUPARI \\ University of Helsinki
}

\begin{abstract}
Habitual religiosity, i.e. the buildup and maintenance of religious habits, hinges on the embodied dimensions of religious memory. The processes involved can be conceptualised using Pierre Bourdieu's theory on the habitus and Paul Connerton's outline of the dynamics of habit-memory and habits. With the help of these theoretical tools, I analyse interview material concerning the daily religious practices of evacuee Karelian Orthodox women, focusing specifically on three basic customs: making the sign of the cross, prayer, and the veneration of icons. These I investigate 1) as practices largely governed by the native layer of the women's habitus; 2 ) as habits that continue to structure the habitus; 3 ) as habits incorporating cultural content; and 4) as customs influenced by the cumulative weight of the women's habit-memory. The discussion offers a view of evacuee Karelian Orthodox women's life-long investment in religion, and shows how in the perpetuation of this form of religiosity, small practices can bear great significance.
\end{abstract}

Keywords: social memory, habitus, habit, embodiment, lived religion, gender, Orthodox Christianity in Finland, Karelian evacuees

Auli:2 I was raised Orthodox. [...] I am of the generation when elementary school started in the fall my mother held prayers at home before sending us to school. I learned a practical [Orthodox way of] life... Since I was a child, to bless myself with the sign of the cross, as was done at home. And to make a cross on top of the [bread] dough and... to avoid evil, practical things like that. The people of those times... Nowadays teaching and theology are stressed a lot, but they did not know all those things; they had this practical everyday religion instead.

1 I thank the two anonymous reviewers, as well as Terhi Utriainen, and Tuula Sakaranaho, for their comments and insights. The writing of the article was funded by the Academy of Finland project entitled Finnish Women Writing on Religion and Gender.

2 The names have been changed to protect the anonymity of my informants. 
In the above quotation, Auli characterises herself as an Orthodox Christian. Her emphasis is on the 'practical everyday religion' she received from her childhood home, which she describes through examples: prayers held before the start of a school year, the everyday use of the sign of the cross, and so on. In this article I discuss the practical everyday religion of women such as Auli - Finnish Orthodox women originally from the area ceded by Finland to the Soviet Union as part of the WW2 peace process. I focus on three basic customs: the sign of the cross, prayer, and keeping and revering icons. Through these customs, my goal is to investigate the women's religiosity as a way of life, a life-long practice and a 'state of the body' (Bourdieu 1990, 68; see also Hervieu-Léger 2000, 72). In particular, I offer a perspective on the role of the embodied dimensions of social memory in the development and perpetuation of this type of religiosity. To delineate the processes involved, I turn to the interrelated concepts of 'habitus', 'habit-memory', and 'habit'.

\section{Habitus, Habit-memory, and Habits}

In Pierre Bourdieu's social theory, the habitus describes the process through which social structures are ingrained in embodied human identity and 'lived through' by the individual. The individual's history in the social world is remembered by her body as dispositions that mediate her future actions in related situations. (Bourdieu 1990, 53-6; McNay 2000, 36-41.) The defining influence of the past, however, remains largely unrecognised by the individual; as 'embodied history' the habitus is 'internalised as second nature and so forgotten as history' (Bourdieu 1990, 56). The habitus is created within and attuned to the surrounding social world - more precisely to a particular 'field' or socio-cultural configuration within the social world (Bourdieu \& Wacquant 1995, 36; McNay 2000, 38). ${ }^{3}$ When the habitus and the field are in sync, the social world appears thoroughly reasonable to the individual. In other words, when the individual's dispositions anticipate

3 Many of Bourdieu's analyses focus on the workings of a particular field (see e.g. Bourdieu \& Wacquant 1995, 132-3). Recently, at least in feminist research, the intermingling of various fields in individuals' lives and their combined effects on the habitus has received more attention (e.g. Adkins 2003; Jokinen 2004; McNay 2000). The habitus of evacuee Karelian Orthodox women as regards religiosity has been affected by a myriad of intertwining fields: religion, family, gender, ethnicity, and economics, to suggest just a few. To accurately describe these various fields is not possible within the scope of this article. I have therefore chosen to speak of the 'field' in an abstract manner, to refer to the structures influencing the women's habitus in a general sense. 
and match the objective structures of the social world, the overall feeling is that of events unfolding as they are supposed to. (Bourdieu 1990, 56-7, 68.) On the other hand, if the social world surrounding the individual evolves, the habitus may fall out of pace with it. When there is a mismatch between habitus and field, the living through of the habitus grows less self-evident. The individual's dispositions no longer perfectly correspond with the functioning of the social world, which can create unanticipated outcomes and make the social world lose some of its common-sense character. (Bourdieu 1990, 62; Bourdieu \& Wacquant 1995, 161-2, 168; Jokinen 2004, 292; McNay 2000, 51-72.)

In the habitus, the individual's 'internalised' and 'embodied' memory of her past functions as an interpretative grid through which every new situation is assessed. The same pattern is identified in Paul Connerton's conception of habit-memory. Habit-memory refers to social memory that is sedimented into the body through culturally specific habitual practices. Habits are practices whose frequent repetition has made conscious deliberation over their performance redundant. This entails that habit-memory is by nature pre-reflexive. While at the moment of their actualisation practices carry a cognitive content (structures, values, principles, categories etc.), this content does not usually reach the level of conscious reflection. Rather, it is the body that in the performance of the practice remembers and understands it. (Connerton 1989, 72-3, 88, 95.) Moreover, according to Connerton, habits come with an inherent impulse to keep performing them. This feature is explained in Bourdieu's theory of the habitus: every repetition of a certain practice reinforces the underlying habit-memory, which in turn fortifies the disposition to repeat the practice once again. (Bourdieu 1990, 56; Connerton 1989, 94; Jokinen 2004, 293-4.) The habitus, in a sense, is a description of the dynamics of habits and habit-memory.

Meredith McGuire (2008) argues that lived religion, religion as it is experienced by individual believers, is based first and foremost on practices. Building on Bourdieu and Connerton, she suggests that 'religious rituals and practices are ways individuals engage their socialised senses in the activation of embodied memory' (McGuire 2008, 100). With McGuire's suggestion as a guideline, I now turn my attention to the basic religious practices of evacuee Karelian Orthodox women. ${ }^{4}$ I view these practices as

4 The term used in Finnish translates as 'Karelian evacuee'. The population of Karelia was in fact 'evacuated' from their original homes to 'mainland' Finland and settled there. I therefore systematically use 'evacuee' here, even though nowadays 'refugee' might be more common. 
religious habits, governed by the women's habitus and their habit-memory concerning religion. ${ }^{5}$

\section{The Religiosity of Evacuee Karelian Orthodox Women}

The two separate wars (1939-40 and 1941-44) fought between Finland and the Soviet Union during WW2 resulted in the double evacuation of altogether over 400000 Finnish Karelians from their homelands (Waris et al. 1952, 17). In the aftermath of WW2, these areas were permanently ceded to the Soviet Union. In 2007 and 2008, I interviewed 26 Finnish Orthodox women who themselves or whose parent(s) had been among the Karelian evacuees. ${ }^{6}$ At the time of the interview the women were on average 75 years old. During the first evacuation from Karelia (winter of 1939/40), most of them had thus been children or teenagers. Three

5 It should be noted that the individual habituses and habit-memories of evacuee Karelian Orthodox women are variants of each other (Bourdieu 1990, 60); to speak of the habitus or the habit-memory of the women in the singular is a generalisation. In the article, I use the terms 'habitus', 'habit-memory', and 'habit' solely in the sense defined above. I use the term 'practice' to refer in a more general sense to totalities of specific skilled acts (Connerton 1989, 94) that are performed repeatedly (e.g. the practice of morning prayer) or larger entities consisting of multiple such totalities (e.g. the practice of praying or Orthodox practice). The term 'custom' I use interchangeably with 'practice' with reference to individual totalities of acts.

6 The interviews form the primary material in my ongoing doctoral study on the religiosity of evacuee Karelian Orthodox women. The study continues along the lines of previous research on the lived religion of (Finnish and Russian) Karelian Orthodox women (e.g. Pentikäinen 1978; Nenola 1986; Keinänen 2003; Järvinen 2004), expanding its geographical and chronological frame to late 20th century Finland.

I contacted potential informants by sending letters to Orthodox parishes and Karelian associations throughout the country, by visiting lay Orthodox associations in the Helsinki area, and by requesting the assistance of colleagues in Northern Karelia (a region in present-day eastern Finland). I interviewed each informant once at her home, the semi-structural interviews lasting on average 2 hours 20 minutes. The interview tapes were transcribed verbatim and stored in the archives of the Finnish Literature Society.

The kind of interview material I have collected, consisting largely of the recollection of past religiosity, is highly constructed. It reflects both the significance of the past for the informant at the time of the interview (Climo \& Cattell 2002, 13, 16-17; Fingerroos \& Haanpää 2006, 33) and the interview situation itself, since the informant always narrates the past taking note of her present audience (Bourdieu 1977, 18; Korkiakangas 1996, 36). Thus it is worth noting, first, that with increasing age many of my informants reported a growing interest in reminiscing about the past (cf. Butler 1963; Saarenheimo 1997, 34-7; Vakimo 2001, 23-6, 73); and, second, that they produced their accounts in response to questions posed by a non-Orthodox and non-Karelian interviewer. In my analysis I have taken into account the nature of the material. Nevertheless, in this article I primarily focus on the content of the women's accounts, not their nature as accounts. 
of the informants were born only after the second evacuation (summer of 1944). ${ }^{7}$

Back in Karelia, the families of most of the informants had lived in Border Karelia, north of Lake Ladoga, in villages with a clear Orthodox majority. Border Karelia was a historically Eastern Orthodox region, with a culture based on an agrarian worldview with many syncretistic elements - although by the eve of WW2 modernisation had gained a foothold there as well (Heikkinen 1989, 56-60; Laitila 1998). The older the informant, the longer she had been able to live in a markedly Orthodox community, where at least some elements of the ethnic Orthodox lifestyle still held good. Anna's account shows how during her childhood in Border Karelia, Orthodoxy was the norm:

Anna: It [Orthodoxy] has certainly given me a lot since childhood. There were not many Lutherans around there. We were just Orthodox. Close where we lived was a chapel, the tsasouna. We stood there on Sundays, with our hair combed and plaited. And stood nicely. At every holiday [...] we were always there. What was really special was that after Easter we could ring the tsasouna bells. When we were in school, we went to ring the bells on the way home [from school]. Yes... Did Orthodoxy give us everything we needed as children?

Wartime brought my informants face to face with a new reality. The Karelian evacuees included two thirds of the Finnish Orthodox population, about 55000 people. The evacuees scattered far and wide, settling mostly in areas that formerly had been all Lutheran (Koukkunen 1982, 59). There was a shortage of Orthodox infrastructure, of priests, and of qualified teachers of Orthodoxy as a school subject; of those of my informants who attended elementary school after WW2, a majority did not have regular instruction in their own religious denomination. (Koukkunen 1982, 100, 119-20, 123-9.) Senja's description of her church experience tells of the conditions in which many of the younger informants were socialised into Orthodoxy.

Senja: Well, the first special event was when we got to go to church in Kuopio. To me it was [special], to see what a church was like *laughs*. It has stayed in my mind.

7 The term 'evacuee Karelian' is commonly used only of people who personally experienced the evacuation(s) (Sallinen-Gimpl 1994, 12), but I use it also of the four informants who either had not yet been born at the time of the evacuations or whose mothers had left the ceded areas before the war(s) to start a family. 
Helena: How old were you?

Senja: I was probably eleven years old.

Helena: Before you got to know...

Senja: Before I got to know what a church is. An Orthodox church, that is. I didn't know because I hadn't seen one. Well, I had when I was a little girl, but I was three or two years old then. You don't remember anything about that.

Additional problems were caused by tensions between newcomers and locals. Karelian evacuees often encountered discrimination (see RaninenSiiskonen 1999, 153-65), and the Orthodox faith was a cause of heightened suspicion. The post-war atmosphere emphasised national homogeneity, one cornerstone of which was Lutheranism (Hämynen 2008, 39-41; Kananen 2010, 63-101; Laitila 2009, 341-3). The joint impact of all these hardships was a low Orthodox self-esteem. Conversion to Lutheranism was not uncommon, and many distinguishing features of Orthodoxy (rituals, religious celebrations etc.) lost at least some of their importance. (Heikkinen 1989, 326-32, 334; Laitila 2009, 342-3.) However, my informants stressed that Orthodoxy remained a strong presence within the childhood home, even if outside the home Lutheranism was the dominant faith.

Of my 26 informants, 22 married a Lutheran and four an Orthodox man. Of those whose husbands were Lutheran, 18 had all their children baptised into the Lutheran Church. This was typical of post-war Finland: nine tenths of all the marriages contracted by Orthodox Church members were with a non-Orthodox spouse, and if the mother was Orthodox and the father Lutheran the children were almost universally baptised as Lutherans (Huotari 1975, 12, 158-65). ${ }^{8}$ Most of my informants were thus the single Orthodox members of their adult family. This setting affected the women's religious practices, especially while there were children living under the same roof. While in their personal religious practice the women usually adhered to Orthodox customs, the children's Lutheranism often set the tone for familial occasions such as church attendance and religious holidays (cf. Huotari 1975). As Sinikka, for example, describes it: 'At that time [after her child was born] I took part in Lutheran activities quite a lot. In a way, my Orthodox practice lessened. I went less to our church and more to a Lutheran one; we went there as a family. It was kind of a phase.' Furthermore, many inform-

8 Before 1970, Finnish law stated that children were primarily baptised according to the religion of the father. The parents could overrule this arrangement, however, with a written agreement. In 1970 the situation was reversed and the mother's religious affiliation became the one favoured by the law. (Huotari 1975, 26.) 
ants describe this period of their life as one during which they had neither the time nor the energy to practice Orthodoxy as diligently as they would have liked. Almost all of the women worked outside the home when their children were small, and the responsibilities of work and the home interfered with their religious life.

Elvi: When I got married, it [active participation in parish life] came to an end. It did surface every once in a while and we did go to church and so on. Still, it wasn't the same. Nevertheless, when I got older, even when my husband was still alive, I started participating more. [...] Now I am very pleased that I have time. And I can do whatever without anyone [interfering]. [...] Nowadays, I think that it [Orthodoxy] is quite a fixed part of my life.

At the time of the interviews, almost all the women were retired. Over half of them were widows and most lived alone. The women had a strong Orthodox identity and were religiously active in various ways: going to Divine Services regularly, frequenting the meetings of the lay Orthodox association, and/or following domestic customs. All of those who had had children were already grandmothers, and family (including when Lutheran) was an important factor in their religious practice, in the form of prayer, religious holidays, cemetery visits and church attendance. Many women, like Elvi in the above excerpt, stressed how retirement had made it possible to concentrate on religious practice more fully than before. On the other hand, many of the women also had to take their poor health into account in planning their religious activities.

The above overview of the religious lives of the evacuee Karelian Orthodox women I have interviewed points towards some of the factors that have influenced and continue to characterise their religiosity. First, there is the childhood socialisation into Orthodoxy: the women have practiced the same religion all their lives. Second, their religious activity: Orthodoxy has remained important to these women throughout their lives. This is by no means a self-evident outcome; many Orthodox women of their age converted to Lutheranism after marrying a Lutheran (cf. Raninen-Siiskonen 1999, 177-80). Third, gender: the women's religious lives echo gendered cultural conventions and convictions concerning religious activity, the bearing of traditions, familial relations and so on (see e.g. Woodhead 2002). Fourth, multiple marginality: the women represent a minority form of Christianity in Finnish society, as well as usually within their own adult families. Fifth, the changing status of Orthodoxy in the surrounding society: during the 
women's lifetime Orthodoxy has gone from the dominant majority Church to a stigmatised minority one and finally to a respected minority one (Hämynen 1996; Kärkkäinen 1999, 206; Laitila 2009). Sixth, the overall change in the surrounding society: the women were born into a modernising agrarian society, but at the time of the interviews lived in a late-modern urban one. During their lifetime, the status of religion as a whole has also altered, in phase with other societal changes. (See e.g. Kääriäinen \& Niemelä \& Ketola 2003; Laitila 1998.) Seventh, the loss factor: the changes mentioned in the two previous points (5 and 6) did not all happen peacefully but through a dramatic rupture: the evacuation from Karelia and the loss of the home. Finally, the age of the informants: several women mention that with increasing age religion has become newly relevant to them (see Teinonen \& Routasalo 2003). In the following analysis, I take note of some of the ways in which these factors have influenced the women's everyday religious habits.

\section{Approaching the Habitus: Evocations of Childhood Religion}

In describing their current religious practices, my informants frequently and spontaneously linked these to similar practices, beliefs and attitudes in their childhood home. Moreover, the women also constructed connections between their religiosity as such and the religion of their childhood surroundings. Whether spontaneously or when asked to describe their present religiosity, the women uniformly grounded it in their childhood religion. The connections were often constructed through everyday practices, such as prayer, the sign of the cross, and the veneration of icons:

Helena: I would like to start with a general question: How would you describe yourself as an Orthodox woman? How might you describe it?

Esteri: Well, we were Orthodox at home... Our daily rhythm went just like my parents had taught me. In the morning, the first thing was to say a prayer, when you had a wash. You cross your eyes, that is, you make the sign of the cross. Always with the mealtime prayer and after you finished eating, you had to make the sign of the cross when leaving the table. It was like a thanks to Orthodoxy. [...] It stuck, the way of the parents. And it has followed me; I have observed [those customs] down to this day.

Toini: Well, I am probably [...] just a normal Orthodox woman. Not too pious, but not a pagan either. Just normal. [...] In the morning and evening, you remember to pray and cross your eyes and so on. It stems from childhood. 
Always before leaving for school you had to cross your eyes, like a blessing, and so on. It's a normal life. You don't pay attention [to it], it happens naturally like eating. [...] It's an everyday thing.

In establishing a link between their present-day religiosity and their childhood religion, the women most often described daily religious life in the childhood home. In Esteri's account above, childhood religion is depicted as being part of everyday life, starting from the first waking moments. Moreover, Esteri defines herself as Orthodox by stating that down to this day she has followed her parents' example in Orthodox practice. Toini too uses a description of the same childhood custom (crossing oneself) to depict her present-day religiosity. She notes, as does Esteri, the regularity of religious practice; it being part of morning and evening routine. Furthermore, she also stresses religion as something 'normal' and 'natural'. It is not something separate from the rest of life but 'happens naturally'. Both these descriptions portray the ease with which in their childhood religion and life in general fitted together - how Orthodoxy was ingrained in everyday rhythms and routines. This tight interlacement of religion and daily life is the anchor to which both Esteri and Toini tie their present-day religiosity. Throughout my material, in similar accounts, evacuee Karelian Orthodox women state that the experience of Orthodoxy as a self-evident aspect of life, realised through recurring customs such as praying and crossing oneself, has continued to characterise their religiosity from childhood down to the present.

Childhood memories, and Karelian evacuees' memories of the lost Karelia, can sometimes be prone to nostalgia, a type of rhetorical idealisation of the past that grows up around the idea of loss (Korkiakangas 1996, 37-8; Raninen-Siiskonen 1999, 101-11). Nostalgic tones can also be discerned in my informants' accounts comparing their childhood religion with a later one. However, the women were also capable of critical reflection concerning the past. Vieno, for instance, distanced herself from the childhood practice of crossing oneself before various chores: '[W]hen my mother started a chore, she always made the sign of the cross. We [Vieno and her siblings] were obviously a bit amazed by it, but when we started weeding we all crossed ourselves. Nowadays it amuses me somehow; today Orthodox families are not quite so rigorous.' What is noteworthy is that as a detailed description of the practice in question, Vieno's account does not differ from other, more positive ones. Generally speaking, the women seemed to take seriously the task of reporting past customs. In most cases, this incentive 
to be informative effectively balanced out the tendency toward nostalgia. (See Saarenheimo 1997, 108, 171.)

In explaining a particular religious practice or defining their religiosity more generally, my informants also focused on the process through which they had originally adopted it. The accounts commonly depict childhood socialisation into Orthodoxy in a passive and embodied manner. Orthodox customs or worldview could for instance be seen as something one has 'grown within' or 'grown into'. Both expressions conjure up the image of an organic process, depicting Orthodoxy either as a nurturing environment or a natural outcome. Taking the metaphor even further, Kirsti eloquently describes the adoption of 'an Orthodox state of mind' as a kind of osmosis. According to her, Orthodoxy 'was transferred through skin contact, through the surrounding atmosphere. Not everything in it can be read [i.e. studied]; part of it is transferred to people unbeknownst to them.'

Giving such descriptions, the women emphasised that Orthodoxy and Orthodox practices were for them not something learned through conscious study but something unconsciously embraced in growing up in an Orthodox environment. In other words, they stressed the importance of childhood socialisation into religion. They also emphasised that in the process religion had become an essential and irremovable part of their lives and their identity. The most effective way to make the point was to use corporeal metaphors that conceived of childhood practices as ingrained in the women's body. Soja, for example, described the sign of the cross as being 'so deep within [her] that it will not come out easily'. Orthodoxy might also be described as residing 'in the back of the head' or being 'stuck to the scalp'. A particularly powerful bodily metaphor is used by Raili, who in the excerpt below compares Orthodoxy 'almost' to a gene. The expression conveys that for Raili, Orthodoxy is fundamental to her very being. Raili ties this feeling to having experienced an 'Orthodox God' in childhood:

Raili: Let's say that I have been Orthodox already since before birth. It is like a second [sic], almost like a gene; it's in you already. So, it feels so hard to imagine, I cannot even imagine being Lutheran, that I would change to Lutheranism. I think that religion has to, it has to start with the child. That you experience having an Orthodox God, even if God is the same for everyone but still...

In their accounts concerning childhood religion as the basis of later religiosity, the interpretations offered by these evacuee Karelian Orthodox women 
come quite close to Pierre Bourdieu's ideas concerning native membership as a particular way of partaking in a field. Bourdieu (who uses the metaphor of a 'game' to describe the social interactions going on in a particular field) notes that the player's belief and investment in the game are the highest when she is 'born into the game', because in that case she is not aware that it is a game - one social construct among others (Bourdieu 1990, 67; see also Connerton 1989, 29-30). In emphasising their socialisation process into Orthodoxy as something unconscious, or saying that they received Orthodoxy in their genes, the informants are in a way describing the process of being born into a game. In addition, in stressing the impossibility of relinquishing Orthodoxy and converting to another faith (which Raili does in the account above) the women are expressing their awareness of how different the situation is when a game such as religion is deliberately adopted. Moreover, since native membership in a field entails the habitus being in sync with it (at least if nothing too dramatic has happened either to the individual or to her surroundings), the result is a world in which everything seems to make sense. The women's descriptions of their childhood religion as an inseparable and natural part of their way of life capture this experience of equivalence between habitus and field. Finally, Bourdieu characterises the practical sense guiding the player as not a state of mind but 'a state of the body' (Bourdieu 1990, 68-9). The corporeal metaphors the informants used to describe their relationship with Orthodoxy are, in my reading, in part a description of the embodiedness of their practical sense of Orthodoxy.

All in all, what I am suggesting is that through the accounts discussed here, the women describe how the native layer of their habitus continues to guide their present-day religious practices. Judging from the accounts, the women's religiosity remains strongly shaped by their childhood experiences and their upbringing in an Orthodox environment. Childhood Orthodoxy - experienced as rhythms, routines, rituals, techniques, gestures, positions, sensations etc. - is rooted in their habit-memory. In describing their everyday childhood practices as the basis of their later religiosity, the women approach a depiction of this embodied knowledge of religion.

\section{The Sign of the Cross, Prayer, and the Veneration of Icons as Religious Habits}

The observance of simple, private and domestic customs such as praying, crossing oneself, and keeping and revering icons, are one aspect of evacuee Karelian Orthodox women's religion that has been preserved to some extent 
intact throughout their lives. Although none of the women claimed to follow childhood practices to the letter (in fact, many reported major changes), usually the women had been able to adapt these particular customs to their different life situations. In one form or another, they have been a part of the women's religiosity all along. In describing their present-day practices of revering icons, praying, and making the sign of the cross, my informants often emphasised their habitual characteristics. In the following two sections I view these customs as habits in the sense outlined by Connerton, taking up both features stressed by him: an impulse to follow the practices regularly and a strong pre-reflexive component.

All of the women had at least one icon on display at their home. Often they had several, in corners and on tables, of different sizes and motifs, sometimes with an oil lamp hanging in front of the icon and/or a traditional käspaikka cloth to cover the frame. In the interviews, the women spoke of their icons with pride. Many informants mentioned that having an icon was something 'self-evident', or that it belonged in the home 'like a clock on the wall'. While icons were in most cases depicted as basic Orthodox paraphernalia, there were contradictory accounts as well. For one thing, it was not uncommon for the women to note that they had 'always' had an icon. The impulse to emphasise one's proper behaviour implies that this was not the case for everyone. As it is, a few of my informants recounted that in the early stages of their marriage they did not have a home icon. As Martta, for instance, put it: 'It's only now that people speak so openly [about their Orthodoxy], but it was not so then. I didn't have an icon at the time' (during the first years of her marriage in the 40s and 50s). (For similar examples see Huotari 1975, 116; Raninen-Siiskonen 1999, 180.) The fact that Martta 'remained silent about' her Orthodoxy at home shows that when the overall environment favoured one religion over the other, the dominant religion easily gained the upper hand even within families.

Several women mentioned regularly lighting an oil lamp or burning candles in front of an icon. A few informants prayed or crossed themselves before an icon daily, while others reverted to these practices on special occasions, such as at times of crisis. The most basic religious practice concerning icons, however, was simply looking at them - or 'resting one's eyes' on them. Tarja, for instance, told of her custom of looking at a particular icon on entering and leaving her home. Tarja's account opens up a view into a daily religion consisting of small and subtle practices. In such religiosity, a glance can be an important religious habit. 
Tarja: And when I come [home] I glance - the icons have to be placed so that when you enter through the door there is one icon that you can immediately spot. So, the last thing before I close the door [in leaving], I look [at the icon]. Then, when I return, I always look [at it] first. It has, the habit has become a thing.

Kirsti: And they [the icons] also have a very important function in that, if a person does not have the time to pray or to practice piety much, glancing at them reminds you of these things. In the same way that when you pass by pictures of your family members, it is enough to glance at your grandchildren or your daughter's or son's family to bring them to your mind, dear as they are. Icons have the same significance; they provide safety and they also bring that dear, important thing silently to you. From the walls, they remind us.

Kirsti too speaks of the significance of having icons at home and of looking at them. She, however, differentiates between 'glancing at icons' and the (more deliberate and demanding) practice of piety. According to Kirsti, icons have an important function as reminders of religion amidst a busy everyday life. As well as instruments of religious practice, then, the informants' icons also worked as aide-memoires. By their mere presence, the icons made religion visible in the women's daily lives - directing their attention to things spiritual. (See Hallam \& Hockey 2001, 77-85.) As Kirsti notes, with icons one doesn't have to consciously practice a specific religious custom to focus on one's faith; instead, the surroundings themselves continuously reflect that faith. Thus the icons created a space for religion in the home, in fact transforming the home into a religious space.

The most common and regular practice mentioned by the women in their descriptions of everyday religion was prayer: in the evening, in the morning, at mealtimes etc. Virtually all the women recounted reciting a prayer or praying in their own words before going to bed at night. Most informants also noted that, in addition to these constants of their day, they prayed whenever the situation called for it - giving thanks to God, 'sighing' towards the sky, or repeating the Jesus Prayer. As to the sign of the cross, many of the women crossed themselves several times a day. It was especially common to make the sign of the cross as part of one's evening and morning prayers; some of them also did it before mealtimes or when entering and leaving the home. On the other hand, a couple of the informants reserved the sign of the cross for such occasions as attending a religious ceremony, going to church or a meeting of the Orthodox lay association, or visiting the 
cemetery. The dwindling use of the sign reflects the general 'Lutheranisation' of Orthodoxy in post-war Finland. Pressed by the normative Lutheran culture, the Orthodox -including some of my informants - suppressed their practices in an effort to fit in. (Heikkinen 1989, 327-8, 334; Huotari 1975, 115; Laitila 2009, 342-3.)

Recurring religious practices, such as praying and crossing oneself, establish rhythms and cycles in daily life. They contribute to the conception of the flow of time, creating punctuations and regularities - time for religion (see Keinänen in print; Munn 1992, 105-9). When repeated frequently throughout the day, praying and crossing oneself contribute to giving everyday life a religious contour. As Soja puts it: ' [Orthodoxy] is here. And every day. And every evening and morning.'

Many of my informants described their domestic practices concerning icons, of praying, and of making the sign of the cross as something they 'always' repeat come a specific time and/or place. While this may be in part strategic (presenting oneself as a good Orthodox woman), the women's focus on regularity still carries weight. Furthermore, it was not uncommon for the women to express an inherent sense of obligation, urgency or inevitability accompanying these practices. They felt compelled to observe them. Senja, for instance, explains that she is incapable of not crossing herself when she wakes up and before going to bed: 'It's been wedged into my head; I can't help doing it'. In describing her custom as something innate, she conveys how the incentive for performing the habit arises from her habit-memory.

Anna: Already when I was little, it felt like the icons were guiding it [life in the childhood home]. It [Orthodoxy] was part of everyday life. Everyday life. We crossed ourselves, as I told you, when we sat down to eat, and when we left the table we did it again. When we got up in the morning we crossed ourselves. At night when we went to bed, we crossed ourselves again. How did it feel so natural? It was part of everyday life. Even today I think that I could not start my daily life in the morning if I wasn't allowed to pray. When I wake up, I sit on the edge of the bed and give thanks for the night. I pray that... God will help me during the day and... for the children, that they will have their health and strength.

In the above account, Anna moves spontaneously from describing the practice of religion in her childhood home to explaining her current practice of morning prayer. She connects the sense of necessity accompanying her practice with her childhood Orthodoxy. Her account approaches the root 
of the force of the women's religious habits. In the habitus, the women's habit-memories turn into dispositions concerning ways of acting in different situations. With every recurring similar experience, the corresponding habit-memory and thereby the disposition are reinforced. This pattern creates a built-in tendency toward stability and a bias towards early experience. (Bourdieu 1990, 53, 60-1.) In Anna's case, every subsequent morning prayer is thus further support for the practical sense that the childhood custom truly is the proper way to start one's day. Thus the women's religious habits perpetuate their existing religiosity (Connerton 1989, 93-4).

\section{The Cultural Contents of Habit-memory}

The evacuee Karelian Orthodox women I interviewed had different attitudes towards discussing the religious signification of their habitual practices. While a few of the informants spontaneously offered theological explanations for their customs, most were not that comfortable with interpreting them. Especially when it came to the sign of the cross, some women were hard put to verbalise what it meant. Martta, for instance, was taken aback by my question as to the meaning of the sign: 'It's the... it's Jesus Christ. My goodness, there's nothing to say except think about Jesus... Jesus.' Rauha too was hesitant to suggest an interpretation of the practice: 'I don't know. I think that it [the sign of the cross], it means everything. Just, like the triune God, it's like that, it means all things... That's what I think, yes.' Although some women seemed a bit intimidated by my position as a scholar of religion (even though I had explained that I am not an expert in theology), and others conveyed a more general apprehension with regard to doctrinal issues, I do not think that either of these was the main reason for Martta's and Rauha's reactions.

Both Bourdieu and Connerton note that cultural content that is incorporated in habit-memory through habitual practices cannot necessarily be made explicit or verbalised. This is because the practices are often adopted and reproduced unconsciously. The body becomes charged with cultural content without active reflection ever taking place. Moreover, once the content is embodied, its common-sense status guards it from conscious attention and scrutiny. This is why habit-memory in fact makes such an effective mnemonic system that societies entrust to it the values and principles they consider most important. (Bourdieu 1977, 94-5; Connerton 1989, 102.) The two women's problems in giving a verbal interpretation of the sign of the cross can be seen to reflect the embodied character of the cultural content 
inscribed in the gesture. Obviously there are verbal explanations of the sign and its symbolism - many informants, for instance, used one that describes it as a threefold blessing (see e.g. Arseni 1999, 237). The significance of the gesture, however, is essentially learned not through theoretical study but by making it: through 'the hidden persuasion of an implicit pedagogy' (Bourdieu 1977, 94) imposed by the surrounding society.

In addition to having trouble explicating the cognitive content of some of their basic religious habits, my informants on occasion also referred more explicitly to the pre-reflexive nature of these practices. As was established in the previous section, many of my informants emphasised the constancy in their daily lives of prayer, crossing oneself, and the veneration of icons. Some also described the performance of these practices - especially the sign of the cross - with adjectives such as 'automatic' and 'routine'. As Elvi, for example, puts it: 'The sign of the cross is a matter of routine in the liturgy. You almost know at which times you cross yourself; in those parts of the service it comes automatically.' Both expressions have the connotation that the performance of the practices is not guided by the conscious mind; they come from one's habit-memory. Elvi thus conveys that it is her body that knows when to make the sign of the cross. The same point is made by Toini: 'You can't make a list of occasions for doing it [i.e. crossing oneself]. When you need it, it comes naturally.' Toini's account is descriptive of the workings of habitus more generally. What she is saying is that the uses of the practice are not known to her in the form of a comprehensive list, a set of rules that would cover all possible instances. Rather, her habitus recognises appropriate situations for making the sign as they come. When this happens, she does not need to reflect upon whether to cross herself or not; her habitus has already made the decision for her. (See Bourdieu 1990, 54; Connerton 1989, 83, 90.)

However, whereas many informants were content to describe their practice of crossing themselves as routine, a couple of the women were not satisfied with this description alone. They stressed that the sign is not a mechanical act, but consists of a mental dimension as well. Consider, for instance, Lempi's account: 'I wouldn't say that you need to reflect on making the sign of the cross every time. But I don't like for it to be done negligently, in passing; it is not that kind of a thing. [...] In a way [you need] to know that this is not any kind of symbol. Because it is simultaneously a credo. You don't cross yourself if you don't believe at all.' Lempi emphasises that the sign of the cross carries significance: it is a declaration of one's faith. However, she does not suggest that the cultural content be thought over on every repetition; one only needs to recognise that it exists. In a way, what 
Lempi is saying is that the practice comes with a proper attitude. Kirsti expresses the same thing in noting that the attitude of 'remembering God' is brought on by crossing oneself: 'The mere attitude, remembering God with love, crossing oneself somewhere like [when] you pass [an icon]; to my mind it is also a moment that touches eternity.'

The women's ability to reflect on the cultural content behind the sign of the cross makes it evident that the custom is not simply habitual but has been a conscious object of study as well, for example at school. Also, the women's reflexivity is further enhanced by their minority status. They have had to explain and justify their practices to others. In this vein, Lempi's remarks above also function to counter negative attitudes concerning Orthodoxy as a ceremonial religion, in contrast with belief-oriented Lutheranism - one of the critiques often raised against the Orthodox faith in the post-war environment (see Kananen 2010, 170-1; Piiroinen 1958, 4-5).

With regard to the cognitive content of their religious habits as such, a certain basic and common essence is discernible from most women's accounts. This cultural message is embedded in the women's habit-memory. In the case of such lifelong practices as those considered here, it is thus not separable from the dispositions the women adopted as children. The cognitive content can be condensed into the idea of dependence: an urgent need for God.

Hilja: Nowadays people don't rely on God the way they used to. I remember from my childhood, there were a lot of old people in the village... They always blessed themselves before starting on whatever chore. [...] Grandma, when she started making bread, she blessed the dough with the sign of the cross and before that she blessed herself. The cows were blessed when the cattle were let out to pasture [in the spring]. [...] And the seed grain was also blessed before sowing.

In the women's childhood religion, as Hilja somewhat nostalgically describes it, recurrent daily practices such as crossing oneself were about putting oneself in the hands of God. The women's present-day practices essentially signify the same thing. The gestures, positions, sights, sounds, and thoughts that these practices consist of elicit - from the women's habit-memory - the attitude of relying on God. Elvi explains this: 'It [the sign of the cross] is coupled with the feeling that you surrender your affairs to a higher [power]. That you ask that power for help. [...] It always involves admitting that you can't run your life by yourself.' 


\section{Evolving Habitus, Changing Habits}

Even though praying, revering icons, and making the sign of the cross have been part of evacuee Karelian Orthodox women's religion throughout their lives, these practices have not been immune to evolution. In the course of their lifetime the women's daily religious customs have in fact undergone considerable transformation. The private and small-scale nature of the customs has probably been a factor protecting them from even more radical alteration (see Sallinen-Gimpl 1994, 311). However, the changes in the women's social surroundings, their life situations and their priorities have been too massive not to have affected their personal religiosity as well.

During the interviews, the informants commonly recognised that the customs under consideration here were not necessarily followed the same way as during childhood, but at the same time insisted on continuity with the childhood religion. This indicates that they had successfully adapted their practices to their new surroundings and situations. The practices remained meaningful to the women; furthermore, they continued to be triggered by more or less the same dispositions as before. On the other hand, the women also spoke of basic religious practices losing their relevance. Customs that earlier had felt self-evident and necessary were no longer so. Revealingly, the women described practices as 'being forgotten', 'slipping', or 'slackening'. Kielo, for example, admits that crossing herself 'has almost become an evening duty. Sometimes [I do it] at the beginning of a meal, but I don't always remember. Yes, these customs are slackening.' The expressions used by Kielo and others depict a situation in which habits are uncontrollably fading away. These metaphors, in my reading, successfully describe a habitus amidst a process of change. Living in a Lutheran-dominated environment, as these women have done for the better part of their lives, has been just one thing eating away at their habit-memory of everyday Orthodoxy. In such a scenario, it is not that one chooses to discard a certain practice; after a long enough history of situations that do not support its use, one's habitus no longer imbues it with the same sense of necessity and urgency as before.

As a historical structure, affected by every experience and realized only in and through these experiences, habitus is not a closed system (Bourdieu 1990, 53; McNay 2000, 43-4). Especially when there is a mismatch between habitus and field, new experiences no longer necessarily reinforce established habit-memories and dispositions but start to alter them. The habitmemory of the evacuee Karelian Orthodox women covered on average 75 years of history, including massive alterations in the surrounding social world (the fields the women were involved in). Some of the layers of their 
habit-memory are traceable from the women's accounts concerning their religious practice. In the following, I focus on one particular layer, that of minority status, and one particular practice, the sign of the cross.

Some of the women's accounts concerning Orthodoxy in wartime and post-war Finland differ clearly from the kinds of descriptions of childhood and present-day religion I have discussed so far. They focus on what it was like to practice Orthodoxy amidst people unfamiliar with Orthodox customs - the reality facing most Orthodox evacuees after they left Karelia. In these accounts, the sign of the cross is not depicted as an unquestioned part of religious practice. It does not come off as something shared by the surrounding community but as something separating one from the rest. In fact, several of the informants described the shyness and shame that accompanied crossing oneself publicly in the post-evacuation context (see also Heikkinen 1989, 332). These feelings arise from the clash between the individual's habit-memory and her conception of the norms of the surrounding social world (Probyn 2004, 239).

Siiri: I think that at that time many children were ashamed of it [crossing themselves], because of the mockery [by the local children]. Of course, it's completely natural for children to laugh at something that they've never seen before, let alone been used to seeing. My mother told someone not to mind about it [the laughter]. That you could see Lutherans pressing their hands together in prayer. That it's the same thing.

Siiri describes the period that the evacuees spent in temporary housing, right after leaving Karelia. The evacuees were often accommodated in local households, and these close contacts brought cultures into conflict. Both sides wondered at the other's ways, but the evacuees, obviously, experienced greater pressure to conform. (Sallinen-Gimpl 1994, 27.) Siiri's account shows that at least young people could be triggered into changing their practices. The attention, the wondering, and the suspicion that Orthodox customs aroused in the Lutheran locals sank into the bodies of the informants, resulting in a new practical sense concerning the sign of the cross: that crossing oneself in public revealed something intimate and compromising about one.

Even after the initial drama surrounding the evacuations had subsided, the lives of the Orthodox evacuees were characterised, much more than they had been in Border Karelia, by their status as a religious minority. This meant that the significance of Orthodoxy within the family (and the religious community) no longer coincided with its role in the overall soci- 
ety. During the first post-war decades, the pressure to adapt to the majority culture remained considerable. Raili, for instance, who was born after the end of the second war, says that although she was raised to cross herself in everyday life, the practice later died down. Her account also includes an apt depiction of the dynamics of habitus, as she concludes that 'it is not [...] up to oneself; it is the environment that shapes the person':

Helena: But in everyday life here at home you don't happen to do it [i.e. cross herself].

Raili: No, no. In the old days, my grandma raised me to do it. Then came the influence of Savo [the eastern Finnish region where Raili then lived]. It's not even necessarily up to oneself; it's the environment that shapes the person. Moreover, when you're younger, at some point you were a bit ashamed of it [crossing oneself]. [...] You got the feeling that you weren't a real person if you were Orthodox. Even though we are true believers.

Vieno, below, notes several subtle impulses that affect her crossing herself in public - and describes the gradual and partial change of her habitus. First, she notes that 'as [she] got older' she has felt more self-conscious about crossing herself at restaurants, which suggests that in her case the change in habitus is due to long-term exposure to Lutheran culture (rather than traumatic short-term experience, as an evacuee for instance). On the other hand, she says that she nevertheless 'can't start eating without' crossing herself, thus acknowledging the continuing influence of the original, childhood dispositions. Vieno's account is a good example of the lag that is part of the habitus: since it is built on the whole past of the individual, it is often slow to change in transitional situations (Bourdieu 1990, 54, 62).

Helena: In what kinds of situations do you cross yourself these days?

Vieno: Well of course at church and at these Orthodox functions at home. Still, at this age, what happens is, or maybe it's a common trend, that when you go out to eat at a restaurant you just do it quickly, [then] start to eat. Inconspicuously. However, somehow it feels that you can't start eating without [doing it].

Helena: Oh, has this started recently, this restaurant thing?

Vieno: Well, not that recently, but as I got older anyway. And the grandchildren, though some of them may roll their eyes a bit, they're used to grandma doing it [i.e. crossing herself], yes. 
Many of the women who admitted feeling embarrassed about crossing themselves in public when they were younger stressed that nowadays the situation is different. Raili ends her above reflection by exclaiming: '[B]eing Karelian and Orthodox is what I'm proud of today!' The change from shame to pride parallels the evolution of the status of Orthodoxy in Finland (cf. Laitila 2009, 343). In essence, however, the contrary feelings reflect the same state of affairs: in post-war Finland, crossing oneself (publicly) was no longer merely a religious gesture, but at the same time a statement. It identified the practitioner as an Orthodox person, a member of a minority.

Many gender-oriented Bourdieu scholars have emphasised that in modern societies individuals partake in various fields that can reinforce, overlap, intertwine with, exclude, and even contradict each other. Their joint effect on the habitus is destabilising, and can result in heightened reflexivity concerning one's habits and the structures that cause them. Heightened reflexivity in turn sometimes (though not automatically) creates opportunities for more political agency and the deliberate acting out of one's identity. (Jokinen 2004, 292, 295; Adkins 2003, 26-7; McNay 2000, 51-2, 56-7.) In the case of evacuee Karelian Orthodox women, their multiple minority status has obviously increased their ability to examine their religiosity - the accounts discussed here being one product of this reflexivity. Moreover, the awareness that results from the experience of being different can permeate the women's religious practice as well, adding a conscious dimension to their religious habits (cf. Adkins 2003; Jokinen 2004). Consider, for instance, Vieno's account above. Vieno recognises that her Lutheran grandchildren take note of her crossing herself before eating, and seems pleased that she is able to 'give them memories of an Orthodox grandmother' (as another informant put it). In other words, even as Vieno follows the dispositions ingrained in her habitus, she is simultaneously performing her Orthodoxy for the benefit of her grandchildren.

\section{Conclusions}

In this article I have investigated three basic religious practices of evacuee Karelian Orthodox women - crossing themselves, praying, and revering icons - from four angles: as customs mainly governed by the native layer of the women's habitus; as habits that continue to sustain their own existence; as habits that incorporate a certain cultural content; and as practices influenced by the cumulative weight of the women's entire past relating to religion. My purpose was to call attention to one aspect of stable and long- 
term religiosity: its habitual character. The above discussion shows that for evacuee Karelian Orthodox women, mundane and small-scale practices can carry large-scale significance. It is through such practices that religion is infused in everyday life, as a constituent of the domestic space and daily routine. Through them, the women have also been able (to some extent) to hold on to a connection with their childhood religion despite the massive changes that have taken place around them - to preserve their 'child's religion' (to use a phrase emphasised by several informants). Moreover, it is in part due to these practices that Orthodoxy has remained topical and relevant for the women throughout their lives. The resilience and influence of the practices, I have argued, is in good part due to their nature as habits.

My other goal was to look at the involvement of embodied social memory in habitual religiosity. The ability of the body to store cultural content in the form of habit-memory is the foundation of any habit. In my analysis of evacuee Karelian Orthodox women's practices, the dynamics concerning habit-memory were clearly visible. The persistence of the habits - and changes in them - showed that habit-memory is based on repetition, but is not immune to change. Rather, it structures religious habits and is structured by them in return, more specifically by the individual's concrete experience concerning every performance of the habit in question. In terms of theory, the above discussion combined Connerton's view of habit-memory as a specific category of (social) memory with Bourdieu's practice-oriented conception of the habitus. I hope to have illustrated that, although not often used in that capacity, Bourdieu's theory makes a fruitful perspective from which to approach the topic of social memory.

Finally, it has been my objective to open up a view, by no means exhaustive, into the religious lives of evacuee Karelian Orthodox women. Their experiences share common features with many other groups of elderly and/or migrant women. My informants have lived through the height of Finland's development from an agrarian society to a late modern urban one. They have witnessed the transformation of Finnish Orthodoxy, first from a local majority denomination to a barely tolerated evacuee one and finally to a widely respected minority one. Through their religious practices these women have participated in, reacted against, and generally positioned themselves in relation to all this turbulence. In the process their everyday religion, notwithstanding its habitual nature, has at times been transformed into a means of resistance, adaptation, or affirmation. More generally speaking, the trajectory of the women's religious lives represents one possible outcome of the combination of long life, life-long investment in religion, and social 
change. This combination enables a perspective into the changing status of religion in modern societies as it is experienced by religious practitioners themselves. The possibilities for research on individual religiosity it offers have yet to be exhausted.

\section{Bibliography}

\section{Adkins, Lisa}

2003 Reflexivity: Freedom or Habit of Gender? - Theory, Culture E Society 20(6) (December 01), 21-42.

\section{Arseni, Archmandrite}

1999 Ortodoksinen sanasto. Helsinki: Otava.

\section{Bourdieu, Pierre}

1990 The Logic of Practice. [Le Sens Pratique.] Trans. Richard Nice. Cambridge: Polity.

1977 Outline of a Theory of Practice. (Cambridge studies in social anthropology, 16.) [Esquisse d'une Théorie de la Pratique, Précédé de Trois Etudes d'Ethnologie Kabyle.] Trans. Richard Nice. Cambridge: Cambridge University Press.

\section{Bourdieu, Pierre, \& Loïc J. D. Wacquant}

1995 Refleksiiviseen sosiologiaan: Tutkimus, käytäntö ja yhteiskunta. [Invitation to Reflexive Sociology.] Trans. Ari Antikainen et al. Joensuu: Joensuu University Press.

\section{Butler, Robert N.}

1963 The Life Review: An Interpretation of Reminiscence in the Aged Psychiatry 26, 65-76.

\section{Climo, Jacob J. \& Maria G. Cattell}

2002 Introduction: Meaning in Social Memory and History: Anthropological Perspectives. - Jacob J. Climo \& Maria G. Cattell (eds), Social Memory and History. Anthropological Perspectives, 1-36. Walnut Creek, CA: AltaMira Press.

\section{Connerton, Paul}

1989 How Societies Remember. (Themes in the social sciences.) Cambridge: Cambridge University Press.

\section{Fingerroos, Outi \& Riina Haanpää}

2006 Muistitietotutkimuksen ydinkysymyksiä. - Outi Fingerroos, Riina Haanpää \& Anne Heimo \& Ulla-Maija Peltonen (eds), Muistitietotut- 
kimus. Metodologisia kysymyksiä, 25-48. Helsinki: Suomalaisen Kirjallisuuden Seura.

\section{Hallam, Elizabeth \& Jenny Hockey}

2001 Death, Memory and Material Culture. (Materializing culture.) Oxford: Berg.

\section{Heikkinen, Kaija}

1989 Karjalaisuus ja etninen itsetajunta. Salmin siirtokarjalaisia koskeva tutkimus. (Joensuun yliopiston humanistisia julkaisuja, 9.) Joensuu: Joensuun yliopisto.

\section{Hervieu-Léger, Danièle}

2000 Religion as a Chain of Memory. [La Religion pour Mémoire.] Trans. Simon Lee. New Brunswick, NJ: Rutgers University Press.

\section{Huotari, Voitto}

1975 Ortodoksin ja luterilaisen avioliitto. Tutkimus uskonto- ja perhetekijöiden vuorovaikutuksesta seka-avioliitoissa Ilomantsissa, Pohjois-Savossa ja Helsingissä. (Suomen teologisen kirjallisuusseuran julkaisuja, 97.) Helsinki: Suomalainen Teologinen Kirjallisuusseura.

\section{Hämynen, Tapio}

2008 Talvi-ja jatkosodan väestönsiirrot Suomessa. - Anssi Mäkinen \& Liisa Honkala \& Kirsti Kujanen \& Joni Strandberg (eds), Suomalaisen arjen historia 4. Hyvinvoinnin Suomi, 26-43. Helsinki: Weilin + Göös.

\section{Hämynen, Tapio}

1996 'Ortodoksi, se oli ryssä ilman muuta'. Suomen ortodoksien identiteetti 1200-luvulta nykypäiviin. - Aamun Koitto 90 (20), 24-8.

\section{Jokinen, Eeva}

2004 Kodin työt, tavat, tasa-arvo ja rento refleksiivisyys. - Eeva Jokinen \& Marja Kaskisaari \& Marita Husso (eds), Ruumis töihin! Käsite ja käytäntö, 285-304. Tampere: Vastapaino.

\section{Järvinen, Irma-Riitta}

2004 Karjalan pyhät kertomukset. Tutkimus livvinkielisen alueen legendaperinteestä ja kansanuskon muutoksista. (Suomalaisen Kirjallisuuden Seuran toimituksia, 962.) Helsinki: Suomalaisen Kirjallisuuden Seura.

\section{Kananen, Heli K.}

2010 Kontrolloitu sopeutuminen. Ortodoksinen siirtoväki sotien jälkeisessä MäSavossa (1946-1959). (Jyväskylä studies in humanities, 144.) Jyväskylä: Jyväskylän yliopisto.

\section{Keinänen, Marja-Liisa}

in print Everyday, Fast and Feast: Household Work and the Production of 
Time in Pre-Modern Russian Orthodox Karelia. - Marion Bowman \& Ülo Valk (eds), Vernacular Religion in Everyday Life. Expressions of Belief. London: Equinox.

2003 Creating Bodies. Childbirth Practices in Pre-Modern Karelia. Stockholm: Stockholm University.

\section{Korkiakangas, Pirjo}

1996 Muistoista rakentuva lapsuus. Agraarinen perintö lapsuuden työnteon ja leikkien muistelussa. (Kansatieteellinen arkisto, 42.) [The Childhood of Memory. The Agrarian Ethos in the Recollection of Childhood Work and Play.] Helsinki: Suomen Muinaismuistoyhdistys.

\section{Koukkunen, Heikki}

1982 Tuiskua ja tyventä. Suomen ortodoksinen kirkko 1918-1978. (Valamon luostarin julkaisuja.) Heinävesi: Valamon luostari.

\section{Kärkkäinen, Tapani}

1999 Kirkon historia. Ortodoksin käsikirja. Joensuu: Ortodoksisen kirjallisuuden julkaisuneuvosto.

\section{Kääriäinen, Kimmo \& Kati Niemelä, \& Kimmo Ketola}

2003 Modernikirkkokansa. Suomalaisten uskonnollisuus uudella vuosituhannella. Tampere: Kirkon tutkimuskeskus.

\section{Laitila, Teuvo}

2009 Epäluuloja, välinpitämättömyyttä ja arvostusta. Ortodoksis-luterilaiset suhteet Suomessa toisen maailmansodan jälkeen ortodoksisesta näkökulmasta. - Hannu Mustakallio (ed.), Terve sielu terveessä ruumiissa. Juhlakirja professori Paavo Kettusen täyttäessä 60 vuotta 27.11.2009, 339-48. Joensuu: Karjalan Teologinen Seura.

1998 Kansanomainen ja kirkollinen ortodoksisuus Raja-Karjalassa. - Pekka Nevalainen \& Hannes Sihvo (eds), Karjala. Historia, kansa, kulttuuri, 383-415. Helsinki: Suomalaisen Kirjallisuuden Seura.

\section{McGuire, Meredith B.}

2008 Lived Religion. Faith and Practice in Everyday Life. Oxford: Oxford University Press.

\section{McNay, Lois}

2000 Gender and Agency. Reconfiguring the Subject in Feminist and Social Theory. Cambridge, UK: Polity Press.

\section{Munn, Nancy D.}

1992 The Cultural Anthropology of Time: A Critical Essay. - Annual Review of Anthropology 21, 93-123.

\section{Nenola, Aili}

1986 Miessydäminen nainen. Naisnäkökulmia kulttuuriin. (Tietolipas, 102.) Helsinki: Suomalaisen Kirjallisuuden Seura. 


\section{Pentikäinen, Juha}

1978 Oral Repertoire and World View. An Anthropological Study of Marina Takalo's Life History. (FF communications, 219.) [Marina Takalon uskonto.] Helsinki: Suomalainen tiedeakatemia.

\section{Piiroinen, Erkki}

1958 Seka-avioliittojen sielunhoito ortodoksiselta kannalta. - Seka-avioliittojen sielunhoito. Järvenpäässä 9.5.1958 pidetyn luterilais-ortodoksisen neuvottelun esitelmät, 3-10. Helsinki: Suomen Yleiskirkollinen Toimikunta.

\section{Probyn, Elspeth}

2004 Shame in the Habitus. - The Sociological Review 52, 224-48.

\section{Raninen-Siiskonen, Tarja}

1999 Vieraana omalla maalla. (Suomalaisen Kirjallisuuden Seuran toimituksia, 766.) Helsinki: Suomalaisen Kirjallisuuden Seura.

\section{Saarenheimo, Marja}

1997 Jos etsit kadonnutta aikaa. Vanhuus ja oman elämän muisteleminen. Tampere: Vastapaino.

\section{Sallinen-Gimpl, Pirkko}

1994 Siirtokarjalainen identiteetti ja kulttuurien kohtaaminen. (Kansatieteellinen arkisto, 40.) Helsinki: Suomen Muinaismuistoyhdistys.

\section{Teinonen, Timo \& Pirkko Routasalo}

2003 Iäkkään rukous. - Gerontologia 17 (2), 65-76, 116.

\section{Vakimo, Sinikka}

2001 Paljon kokeva, vähän näkyvä. Tutkimus vanhaa naista koskevista kulttuurisista käsityksistä ja vanhan naisen elämänkäytännöistä. (Suomalaisen Kirjallisuuden Seuran toimituksia, 818.) Helsinki: Suomalaisen Kirjallisuuden Seura.

\section{Waris, Heikki \& Vieno Jyrkilä \& Kyllikki Raitasuo \& Jouko Siipi}

1952 Siirtoväen sopeutuminen. Tutkimus Suomen karjalaisen siirtoväen sosiaalisesta sopeutumisesta. Helsinki: Otava.

\section{Woodhead, Linda}

2002 Women and Religion. - Linda Woodhead (ed.), Religions in the Modern World. Traditions and Transformations, 332-55. London: Routledge. 